\title{
PERBEDAAN AKTIVITAS FISIK INTENSITAS BERAT, ASUPAN ZAT GIZI MAKRO, PERSENTASE LEMAK TUBUH, DAN LINGKAR PERUT ANTARA PEKERJA BAGIAN PRODUKSI DAN ADMINISTRASI PT. PUPUK KUJANG CIKAMPEK
}

\author{
Zeza Aziza, Fillah Fithra Dieny ${ }^{*}$ \\ Program Studi Ilmu Gizi Fakultas Kedokteran Universitas Diponegoro \\ J1.Dr.Sutomo No.18, Semarang, Telp (024) 8453708, Email : gizifk@ undip.ac.id
}

\begin{abstract}
Background: Production workers had a heavier workload than administrative workers. Workload will affect physical activity and nutrients intake which can cause workers to the risk occurrence of problems with nutritional status workers.

Objective: Analyze differences in vigourus intensity physical activity, macro-nutrient intake, body fat percentage, and waist circumference among production and administrative workers.

Methods: This research was observational analytic cross sectional. Subjects were male workers aged 20-40 years. Subjects were obtained by purposive sampling, large research subjects were 35 people of administrative workers and 35 people of production workers. The data collected in this research was the sample identity, body fat percentage, waist circumference, macro-nutrient intake with the FFQ, and physical activity using a questionnaire. Normality test using the Shapiro Wilk. Statistical analyze using independent t-test and Mann-Whitney.

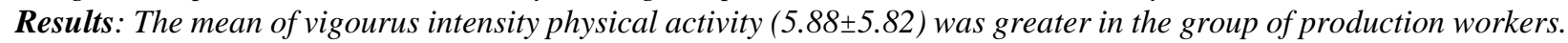
The mean intake of energy, protein, fat, and carbohidrate were higher in the group of production workers than group of administrative. Body fat percentage and waist circumference in both groups were mostly within the normal and over ranges. There were significant different in the vigorous intensity of the physical activity $(p=0.000)$, as well as energy intake $(p=0.015)$ and fat intake $(p=0.030)$, but there were no different of body fat percentage $(p=0.676)$, waist circumference $(p=0.417)$, protein intake $(0.057)$, and carbohydrate intake $(p=0.074)$ between the two groups.

Conclusions: There were different of vigorous intensity physical activity, energy intake, and fat intake between administrative and production workers. Vigorous intensity physical activity, energy intake, and fat intake were higher in production workers than administrative workers.

Keywords: physical activity, nutrition intake, body fat percentage, waist circumference
\end{abstract}

\begin{abstract}
ABSTRAK
Latar Belakang : Pekerja bagian produksi mempunyai beban kerja berat dibandingkan pekerja bagian administrasi. Beban kerja akan mempengaruhi aktivitas fisik dan asupan zat gizi pekerja yang dapat menyebabkan risiko terjadinya masalah status gizi pekerja.

Tujuan : Menganalisis perbedaan aktivitas fisik intensitas berat, asupan zat gizi makro, persentase lemak tubuh, dan lingkar perut antara pekerja bagian produksi dan pekerja bagian administrasi.

Metode : Jenis penelitian adalah analitik observasional cross sectional. Subjek penelitian adalah pekerja laki-laki usia 20-40 tahun. Subjek diambil dengan cara purposive sampling, besar subjek penelitian adalah 35 orang pekerja administrasi dan 35 orang pekerja produksi. Data yang dikumpulkan adalah identitas sampel, persentase lemak tubuh, lingkar perut, asupan zat gizi makro dengan FFQ, dan aktivitas fisik menggunakan kuesioner. Uji normalitas menggunakan Shapiro Wilk. Analisis statistik menggunakan independent t-test dan Mann-Whitney.

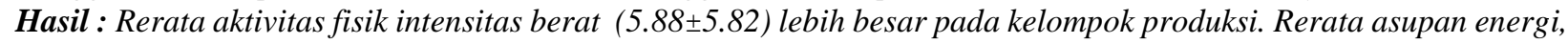
protein, lemak, dan karbohidrat lebih tinggi pada kelompok produksi dibandingkan kelompok administrasi. Persentase lemak tubuh dan lingkar perut pada kedua kelompok sebagian besar dalam kategori normal dan lebih. Terdapat perbedaan bermakna aktivitas fisik intensitas berat $(p=0.000)$, asupan energi $(p=0.015)$ dan asupan lemak $(p=0.030)$, namun tidak ada perbedaan bermakna persentase lemak tubuh $(p=0.676)$, lingkar perut $(p=0.417)$, asupan protein $(p=0.057)$, dan karbohidrat $(p=0.074)$ pada kedua kelompok pekerja.

Simpulan : Terdapat perbedaan pada aktivitas fisik intensitas berat, asupan energi, dan asupan lemak antara pekerja administrasi dan pekerja produksi. Aktivitas fisik intensitas berat, asupan energi dan asupan lemak lebih tinggi pada pekerja produksi dibandingkan pekerja administrasi.
\end{abstract}

Kata kunci : aktivitas fisik, asupan zat gizi, persentase lemak tubuh, lingkar perut

\section{PENDAHULUAN}

Sumber daya manusia merupakan aset utama bagi perusahaan baik secara langsung maupun tidak langsung dalam menentukan maju mundurnya suatu perusahaan sehingga sangat penting diperhatikan. ${ }^{1}$ Pekerja bagian produksi dan pekerja bagian administrasi membutuhkan zat gizi untuk tetap sehat dan produktif, serta mengekang

\footnotetext{
*)Penulis Penanggungjawab
} 
kelaparan sekaligus menurunkan risiko terjadinya penyakit. ${ }^{2,3}$ Beban kerja merupakan beban yang ditanggung pekerja sesuai dengan jenis pekerjaannya berupa aktivitas fisik, mental, dan sosial. $^{5,6}$ Berat ringannya beban kerja sangat dipengaruhi oleh jenis aktivitas (sebagai beban utama) dan lingkungan kerja (sebagai beban tambahan). ${ }^{5}$ Aktivitas fisik pada saat bekerja merupakan kemungkinan yang diduga menyebabkan terjadinya peningkatan kejadian obesitas. $^{7}$

Beban kerja yang berat dapat menyebabkan kelelahan maupun stress kerja sehingga memiliki risiko terjadinya dua kecenderungan gangguan pola makan yaitu tidak nafsu makan ataupun bertambah makan terutama yang manis. ${ }^{5,8}$ Asupan zat gizi pekerja sehari-hari dapat dipengaruhi oleh lingkungan dan makanan saat di rumah. Selain itu, pengadaan makanan dengan cara memberikan uang makan kepada pekerja dapat memungkinkan terjadinya perbedaan asupan makanan pekerja baik secara kualitatif maupun secara kuantitatif.

Beban kerja mempunyai peranan penting dalam menentukan kebutuhan energi. ${ }^{9}$ Pekerja bagian produksi mempunyai beban kerja berat sehingga berisiko mengalami penurunan berat badan jika tidak seimbang dengan asupan gizi yang cukup, sebaliknya pekerja bagian administrasi mempunyai risiko mengalami kelebihan berat badan karena beban kerja ringan dengan asupan zat gizi yang berlebih. ${ }^{9}$ Tidak menutup kemungkinan pada pekerja produksi maupun pada pekerja administrasi mempunyai masalah status gizi yang sama dilihat dari faktor yang mempengaruhi status gizi pekerja seperti asupan makan secara kualitatif serta kuantitatif, aktivitas fisik, beban kerja, lingkungan kerja, dan kapasitas kerja.., 10

Obesitas menjadi masalah kesehatan di masyarakat yang signifikan, dimana tingkat obesitas pada pekerja telah meningkat dalam beberapa tahun terakhir. ${ }^{11}$ Sebanyak 250 juta orang di dunia mengalami kelebihan berat badan, dan jumlah ini diperkirakan akan meningkat mencapai 300 juta orang pada tahun $2025 .^{2}$ Kelebihan berat badan terjadi lebih dari $30 \%$ dialami orang dewasa dan $17 \%$ pada remaja di amerika. ${ }^{3}$ Kelebihan berat badan karena terjadinya peningkatan lemak tubuh dapat berkaitan dengan risiko dari morbiditas dan mortalitas tubuh yang menjadi faktor sindrom metabolik. ${ }^{12,13}$ Masalah status gizi yang terjadi di individu dapat diketahui dengan cara pengukuran komposisi total lemak tubuh dari berat badan atau persentase lemak tubuh (PLT).

Berdasarkan survey awal menurut hasil medical check up PT Pupuk Kujang pada tahun
2012 prevalensi masalah gizi lebih untuk kasus obesitas di perusahaan cenderung mengalami peningkatan yaitu dari 9,0\% pada tahun 2011 menjadi 10,8\% pada tahun 2012 yang lebih banyak terjadi pada kelompok usia produktif yaitu usia 20 40 tahun. Selain itu dari data survey pendahuluan ditemukan adanya pekerja yang mengalami sindrom metabolik, dilihat dari prevalensi kejadian terbesar pada pekerja dengan hiperkolesterol sebesar 34,5\%, hipertrigliserid $28,3 \%$, dan glukosa darah sebesar $18,9 \%$.

Menurut penelitian prediksi terbaik untuk obesitas yang merupakan konsekuensi dari risiko sindrom metabolik adalah dengan mengukur lemak visceral. ${ }^{14}$ Dibandingkan dengan populasi barat, populasi Asia memiliki jaringan adiposa viseral lebih banyak sehingga untuk mengukur risiko dari penyakit kardiovaskular yang sensitif terhadap risiko metabolik salah satunya dengan pengukuran lingkar perut (LP). ${ }^{15}$ Selain itu, prevalensi LP lebih banyak terjadi pada laki-laki dibandingkan dengan perempuan. ${ }^{15}$ Pekerja di PT Pupuk Kujang sebagian besar terdiri dari laki-laki sehingga pengukuran LP dapat efektif digunakan.

Berdasarkan uraian tersebut maka penulis tertarik untuk melakukan penelitian apakah ada perbedaan aktivitas fisik intensitas berat, asupan zat gizi makro (energi, protein lemak dan karbohidrat), persentase lemak tubuh, dan lingkar perut antara pekerja bagian produksi dan administrasi PT Pupuk Kujang Cikampek.

\section{METODE}

Penelitian dilakukan di PT Pupuk Kujang Cikampek Jawa Barat pada bulan Juni 2014. Penelitian termasuk penelitian analitik observasional di bidang gizi masyarakat dengan pendekatan keilmuan gizi kerja menggunakan rancangan cross sectional.

Populasi dalam penelitian adalah semua pekerja laki-laki di PT Pupuk Kujang Cikampek Jawa Barat. Berdasarkan perhitungan menggunakan rumus estimasi proporsi didapatkan total subjek minimal dengan drop out $10 \%$ dari 2 kelompok adalah 70 subjek, dan dalam penelitian ini diperoleh 70 subjek dengan kelompok pekerja bagian produksi 35 subjek dan kelompok pekerja bagian administrasi 35 subjek yang menggunakan metode purposive sampling. Subjek dipilih sesuai dengan kriteria inklusi yaitu pekerja laki-laki yang berusia 20 - 40 tahun, bersedia menjadi responden dalam penelitian, tidak dalam keadaan sakit atau dalam perawatan dokter, untuk kelompok 1 merupakan pekerja bagian produksi dengan posisi kerja banyak berdiri dan lebih banyak menggunakan tenaga fisik 
dalam melakukan pekerjaannya, dan untuk kelompok 2 merupakan pekerja bagian kantor dengan posisi kerja banyak duduk dan lebih banyak menulis ataupun mengetik di depan komputer dalam melakukan pekerjaannya.

Data yang dikumpulkan dalam penelitian ini adalah identitas sampel, aktivitas fisik intensitas berat, asupan zat gizi makro (energi, lemak, karbohidrat, dan protein), persentase lemak tubuh, dan lingkar perut. Aktivitas fisik adalah gerak tubuh yang timbul oleh otot-otot skeletal atau kegiatan yang melibatkan fisik (tubuh) sehingga mengakibatkan pengeluaran energi baik pada saat melakukan pekerjaan maupun pada saat diluar pekerjaan, diketahui melalui kuesioner aktivitas fisik yang di hitung waktu (jam/minggu) yang digunakan subjek dalam melakukan aktivitas fisik intensitas berat dilihat dari intensitasnya dengan kemudian dikategorikan berdasarkan rekomendasi World Health Oraganization (WHO). ${ }^{16,17}$ Dikatakan aktivitas fisik intensitas berat adalah jika aktivitas fisik mempunyai jumlah MET (Metabolic Energy Turnover) per aktivitas > 6 MET seperti mengangkat beban berat, bersepeda, dan lainnya. Sedangkan aktivitas fisik dikatakan intensitas sedang jika jumlah MET per aktivitas 3 - 6 MET seperti senam, golf, berjalan perlahan, dan lainnya. ${ }^{21}$

Asupan zat gizi makro berupa asupan energi, lemak, karbohidrat, dan protein. Asupan energi adalah asupan energi dari semua makanan dan minuman yang dikonsumsi dalam satu hari oleh responden dan dinyatakan dalam satuan kalori (kkal). Asupan lemak adalah asupan lemak dari semua makanan dan minuman yang dikonsumsi dalam satu hari oleh responden dan dinyatakan dalam satuan gram (gr). Asupan karbohidrat adalah asupan karbohidrat dari semua makanan dan minuman yang dikonsumsi dalam satu hari oleh responden dan dinyatakan dalam satuan gram (gr). Asupan protein adalah asupan lemak dari semua makanan dan minuman yang dikonsumsi dalam satu hari oleh responden dan dinyatakan dalam satuan gram (gr). Asupan zat gizi makro diperoleh menggunakan Food Frequency Quesioner (FFQ) Semi Quantitative. Hasil analisa konsumsi kemudian dibandingkan dengan tingkat kecukupan energi individu dari perbandingan BB aktual dan BB pada Angka Kecukupan Gizi (AKG) 2004. Hasil rerata asupan dengan angka kecukupan individu dikalikan $100 \%$ sehingga didapatkan persen tingkat kecukupan asupan zat gizi makro dimana dikategorikan kurang $<80 \%$, baik $80 \%-$ $110 \%$, dan lebih $>110 \% .^{18}$

Persentase lemak tubuh (PLT) adalah jumlah total lemak dalam tubuh yang dibandingkan dengan berat badan, hasil dari pengukuran kemudian disesuaikan kategorinya dengan tabel klasifikasi PLT Tanita 2011 didasarkan NIH dan WHO dalam penenelitian obesitas yang dilakukan oleh Gallagher. ${ }^{19,20}$ Lingkar perut (LP) adalah ukuran lingkar perut yang menggambarkan deposit lemak dalam tubuh, dimana LP dikatakan normal jika $\mathrm{LP} \leq 90 \mathrm{~cm}$ dan overfat jika LP $>90 \mathrm{~cm} \cdot{ }^{13,21}$ Penimbangan berat badan menggunakan timbangan injak digital dengan ketelitian $0,1 \mathrm{~kg}$. Pengukuran tinggi badan menggunakan microtoa dengan ketelitian $0,1 \mathrm{~cm}$. pengukuran PLT menggunakan Bioelectrical Impedance Analyzer (BIA). Pengukuran LP menggunakan pita meteran dengan ketelitian $0,1 \mathrm{~cm}$.

Analisis data menggunakan program Statistic Package For The Social Science (SPSS) versi 20. Analisis univariat untuk mengetahui nilai minimum dan maksimum, rerata, standar deviasi serta tabel distribusi frekuensi PLT, LP aktivitas fisik intensitas berat, dan asupan zat gizi makro. Sebelum uji hipotesis, dilakukan uji kenormalan dengan Saphiro Wilk. Perbedaan PLT, LP, dan asupan zat gizi makro (energi, lemak, karbohidrat, dan protein) antara pekerja bagian produksi dan administrasi menggunakan uji independent t-test, sedangkan perbedaan aktivitas fisik intensitas berat pada kedua kelompok pekerja menggunakan uji Mann-Whitney.

\section{HASIL PENELITIAN}

Jumlah subjek pada penelitian ini adalah 70 pekerja yang dibagi menjadi kelompok pekerja administrasi $(\mathrm{n}=35)$ dan kelompok pekerja produksi $(n=35)$. Distribusi frekuensi aktivitas fisik intensitas berat, asupan zat gizi makro, persentase lemak tubuh, dan lingkar perut, dapat dilihat pada tabel 1 .

Tabel 1. Distribusi Frekuensi Aktivitas Fisik Intensitas Berat, Asupan Energi, Asupan Protein, Asupan Lemak, Asupan Karbohidrat, Persentase Lemak Tubuh, Lingkar Perut

\begin{tabular}{lcccc}
\hline \multicolumn{1}{c}{ Variabel } & \multicolumn{2}{c}{ Administrasi } & \multicolumn{2}{c}{ Produksi } \\
\cline { 2 - 6 } & $\mathbf{n}$ & $\boldsymbol{\%}$ & $\mathbf{n}$ & $\boldsymbol{\%}$ \\
\hline $\begin{array}{l}\text { Aktivitas Fisik } \\
\text { - Tidak Memenuhi Rekomendasi }\end{array}$ & - & - & - & - \\
- Memenuhi Salah Satu Rekomendasi ${ }^{1}$ & 22 & 62.9 & 9 & 25.7 \\
\hline
\end{tabular}




\begin{tabular}{|c|c|c|c|c|}
\hline - Memenuhi Seluruh Rekomendasi 1,2 & 13 & 37.1 & 26 & 74.3 \\
\hline \multicolumn{5}{|l|}{ Asupan Energi (kkal) } \\
\hline - Kurang & 15 & 42.9 & 3 & 8.6 \\
\hline - Baik & 18 & 51.4 & 24 & 68.6 \\
\hline - Lebih & 2 & 5.7 & 8 & 22.9 \\
\hline \multicolumn{5}{|l|}{ Asupan Protein (gr) } \\
\hline - Kurang & - & - & - & - \\
\hline - Baik & 7 & 20.0 & - & - \\
\hline - Lebih & 28 & 80.0 & 35 & 100.0 \\
\hline \multicolumn{5}{|l|}{ Asupan Lemak (gr) } \\
\hline - Kurang & 15 & 42.9 & 4 & 11.4 \\
\hline - Baik & 10 & 28.6 & 9 & 25.7 \\
\hline - Lebih & 10 & 28.6 & 22 & 62.9 \\
\hline \multicolumn{5}{|l|}{ Asupan Karbohidrat (gr) } \\
\hline - Kurang & 13 & 37.1 & 4 & 11.4 \\
\hline - Baik & 16 & 45.7 & 19 & 54.3 \\
\hline - Lebih & 6 & 17.1 & 12 & 34.3 \\
\hline \multicolumn{5}{|l|}{ Persentase Lemak Tubuh (\%) } \\
\hline - Underfat & 5 & 14.3 & - & - \\
\hline - Normal & 14 & 40.0 & 19 & 54.3 \\
\hline - Overfat & 9 & 25.7 & 9 & 25.7 \\
\hline - Obese & 7 & 20.0 & 7 & 20.0 \\
\hline \multicolumn{5}{|l|}{ Lingkar Perut (cm) } \\
\hline - Normal & 22 & 62.9 & 28 & 80 \\
\hline - Overfat & 13 & 37.1 & 7 & 20 \\
\hline
\end{tabular}

1 minimal melakukan 150 menit aktivitas fisik intensitas sedang dalam seminggu

${ }^{2}$ minimal melakukan 75 menit aktivitas fisik intensitas berat dalam seminggu

Berdasarkan tabel 1, diketahui bahwa subjek penelitian pada kedua kelompok pekerja telah memenuhi rekomendasi aktivitas fisik WHO. Asupan energi dan asupan karbohidrat pada kedua kelompok sebagian besar dalam kategori baik. Dilihat dari asupan energi, protein, lemak dan karbohidrat dalam kategori lebih pada kelompok pekerja produksi lebih banyak ditemukan jika dibandingkan kelompok pekerja administrasi. Sedangkan dalam kategori kurang untuk asupan energi, lemak, dan karbohidrat pada kelompok pekerja administrasi lebih banyak ditemukan jika dibandingkan kelompok pekerja produksi. Asupan protein kategori lebih ditemukan di seluruh subjek pada kelompok pekerja produksi (100\%), sedangkan pada kelompok pekerja administrasi asupan protein dalam kategori baik (20\%) dan lebih (80\%). Asupan lemak pada kelompok pekerja administrasi sebanyak $42.9 \%$ lebih besar terdapat untuk kategori kurang, sedangkan pada kelompok pekerja produksi asupan lemak sebanyak $62.9 \%$ lebih besar terdapat pada kategori lebih.

Tabel 1 menunjukkan bahwa PLT dan LP pada kedua kelompok pekerja banyak ditemukan dalam kategori normal dan lebih. Frekuensi berdasarkan PLT dalam kategori kurang hanya ditemukan pada kelompok pekerja administrasi yaitu sebanyak 5 orang (14.3\%). Jumlah dengan overfat yang dilihat berdasarkan LP pada kelompok pekerja administrasi (37.1\%) lebih banyak jika dibandingkan dengan kelompok pekerja produksi (20\%).

Perhitungan nilai minimum, maksimum, rerata, simpangan baku, dan penilaian uji statistik aktivitas fisik intensitas berat, asupan zat gizi makro, persentase lemak tubuh, dan lingkar perut dapat dilihat pada tabel 2.

Tabel 2. Nilai Minimum, Maksimum, dan Mean \pm SD

\begin{tabular}{|c|c|c|c|c|c|c|c|}
\hline \multirow{2}{*}{ Variabel } & \multicolumn{3}{|c|}{ Administrasi } & \multicolumn{3}{|c|}{ Produksi } & \multirow[b]{2}{*}{ p } \\
\hline & $\min$ & $\max$ & mean \pm SD & $\min$ & $\max$ & mean \pm SD & \\
\hline $\begin{array}{l}\text { Total Frekuensi } \text { Aktivitas } \\
\text { Fisik Intensitas Berat } \\
\text { (jam/minggu) }\end{array}$ & 0 & 4.6 & 1.3 & 0.3 & 22.7 & $5.88 \pm 5.82$ & $0^{\mathrm{b}, \mathrm{c}}$ \\
\hline Asupan Energi (kkal) & 1800 & 3811 & $2527.73 \pm 546$ & 2066 & 4164 & $2831.68 \pm 557.52$ & $0.015^{\mathrm{a}, \mathrm{c}}$ \\
\hline Asupan Protein (gr) & 40 & 209 & $114.95 \pm 36.77$ & 76 & 209 & $131.60 \pm 35.28$ & $0.057^{\mathrm{a}}$ \\
\hline Asupan Lemak (gr) & 28 & 166 & $78.65 \pm 30.97$ & 36 & 176 & $94.99 \pm 30.59$ & $0.030^{\mathrm{a}, \mathrm{c}}$ \\
\hline Asupan Karbohidrat (gr) & 185 & 649 & $393.49 \pm 119.27$ & 279 & 662 & $437.35 \pm 77.78$ & $0.074^{\mathrm{a}}$ \\
\hline
\end{tabular}




\begin{tabular}{|c|c|c|c|c|c|c|c|}
\hline $\begin{array}{l}\text { Persentase Lemak Tubuh } \\
(\%)\end{array}$ & 5 & 34.9 & $19.81 \pm 7.46$ & 11.4 & 31.4 & $20.46 \pm 5.38$ & $0.676^{\mathrm{a}}$ \\
\hline Lingkar Perut (cm) & 65 & 120.8 & $86.38 \pm 13.30$ & 69.7 & 105.3 & $84.13 \pm 9.46$ & $0.417^{\mathrm{a}}$ \\
\hline
\end{tabular}

Berdasarkan tabel 2 rerata total frekuensi aktivitas fisik intensitas berat pada kelompok pekerja produksi $(5.88 \pm 5.82)$ jauh lebih besar dibandingkan pada kelompok pekerja administrasi $(1.37 \pm 1.20)$ dengan nilai maksimum total frekuensi aktivitas fisik intensitas berat pada kelompok pekerja produksi adalah $22.7 \mathrm{jam} / \mathrm{minggu}$. Secara garis besar rerata asupan zat gizi makro yang meliputi energi, protein, lemak, dan karbohidrat lebih tinggi pada kelompok pekerja produksi jika dibandingkan dengan kelompok pekerja administrasi. Rerata PLT pada kelompok pekerja administrasi (19.81 \pm 7.46$)$ lebih rendah dibandingkan dengan kelompok pekerja produksi (20.46 \pm 5.38 ), namun untuk rerata LP pada kelompok pekerja administrasi $(84.13 \pm 9.46)$ lebih tinggi dibandingkan dengan kelompok pekerja produksi $(86.38 \pm 13.30)$. Nilai minimum PLT dan LP pada pekerja administrasi lebih rendah dibandingkan pada pekerja produksi.

Hasil uji statistik menunjukkan bahwa terdapat perbedaan signifikan pada total frekuensi aktivitas fisik intensitas berat $(\mathrm{p}=0.000)$, asupan energi $(\mathrm{p}=0.015)$, dan asupan lemak $(\mathrm{p}=0.030)$ antara kelompok pekerja administrasi dan kelompok pekerja produksi, sedangkan pada variabel PLT, LP, asupan protein dan asupan karbohidrat pada kedua kelompok pekerja tidak menunjukkan perbedaan yang bermakna.

\section{PEMBaHASAN}

Pada penelitian ini sebagian besar aktivitas fisik pekerja administrasi dan pekerja produksi telah memenuhi rekomendasi aktivitas fisik WHO yaitu melakukan aktivitas sedang selama 2,5 jam/minggu atau melakukan aktivitas berat selama 1,25 jam/minggu. Beban kerja berat lebih banyak dialami oleh kerja fisik, dimana beban kerja fisik dapat berupa beratnya pekerjaan seperti mengangkat, mengangkut, merawat, dan mendorong. ${ }^{22}$ Sedangkan beban kerja ringan cenderung dialami oleh kerja nonfisik yang dapat berupa sejauh mana tingkat keahlian dan prestasi kerja yang dimiliki individu dengan individu lainnya. ${ }^{22}$ Pada penelitian ini rerata total frekuensi aktivitas fisik intensitas berat jauh lebih tinggi pada pekerja produksi. Hal ini membuktikan bahwa total frekuensi aktivitas fisik intensitas berat kelompok pekerja produksi lebih tinggi dibandingkan dengan kelompok pekerja administrasi.
Penelitian sebelumnya mengungkapkan bahwa semakin lama waktu yang digunakan untuk melakukan aktivitas fisik intensitas berat maka status gizi cenderung semakin rendah, ${ }^{23}$ sehingga pada kelompok pekerja produksi dan kelompok pekerja administrasi dapat berisiko mengalami masalah status gizi jika waktu yang digunakan untuk melakukan aktivitas fisik intensitas berat tidak diimbangi dengan asupan zat gizi yang cukup.

Hasil analisis bivariat pada penelitian ini menunjukkan adanya perbedaan yang bermakna untuk total frekuensi aktivitas fisik intensitas berat antara kelompok pekerja administrasi dan kelompok pekerja produksi, hal ini membuktikan kedua kelompok pekerja mempunyai aktivitas fisik yang berbeda baik secara frekuensi maupun jenis aktivitas fisik yang dilakukan. Hasil ini berbeda dengan hasil penelitian pada pekerja yang menemukan tidak adanya perbedaan antara aktivitas fisik pada pekerja dalam ruangan dengan pekerja lapangan. ${ }^{24}$ Waktu yang digunakan untuk melakukan aktivitas fisik intensitas berat pada kelompok pekerja administrasi lebih sedikit dikarenakan kegiatan lebih banyak duduk saat bekerja dan olahraga yang biasa dilakukan adalah olahraga dengan intensitas ringan seperti senam yang dilakukan 0 sampai 1 hari seminggu, sedangkan pada pekerja produksi lebih banyak disebabkan karena aktivitas yang sering dilakukan oleh kelompok pekerja produksi adalah mengangkat beban berat, berdiri, dan berjalan serta tetap melakukan olahraga seperti fitness dan badminton yang dilakukan 1 sampai 3 kali seminggu.

Asupan zat gizi pada pekerja mempunyai peranan baik bagi kesejahteraan maupun dalam rangka meningkatkan disiplin dan produktivitas pekerja. $^{25}$ Dari data FFQ pada penelitian ini diketahui bahwa rerata asupan zat gizi makro berupa energi, protein, lemak maupun karbohidrat pada pekerja administrasi lebih rendah dibandingkan pada pekerja produksi. Hal tersebut disebabkan karena kelompok pekerja administrasi hanya makan dua kali sehari dan jarang/tidak ada makanan selingan, ${ }^{26}$ selain itu tingginya nafsu makan setelah bekerja pada pekerja produksi sehingga asupan makan yang dikonsumsi pada pekerja produksi lebih tinggi dibandingkan pada pekerja administrasi. Nilai rerata asupan energi yang tinggi pada kelompok pekerja produksi menggambarkan bahwa frekuensi dan jumlah 
makanan yang dikonsumsi kelompok pekerja produksi lebih banyak dibandingkan kelompok pekerja administrasi. Penelitian ini juga menunjukkan bahwa sebagian besar asupan protein pada kedua kelompok pekerja dalam kategori lebih. Tingginya asupan protein dapat disebabkan dari jenis konsumsi makanan yang lebih banyak ke makanan tinggi protein nabati dan hewani seperti tahu, tempe, dan telur.

Rerata untuk asupan lemak pada kelompok pekerja administrasi sebagian besar berada dalam kategori kurang, sedangkan nilai rerata asupan lemak pada kelompok pekerja produksi sebagian besar berada dalam kategori lebih. Hal tersebut dapat disebabkan karena jenis dan juga frekuensi maupun jumlah asupan makanan sumber lemak yang tinggi pada kelompok pekerja produksi seperti susu, santan, dan minyak. Sedangkan untuk rerata asupan karbohidrat pada kelompok pekerja administrasi lebih rendah dibandingkan pada kelompok pekerja produksi, namun pada kedua kelompok diketahui bahwa asupan karbohidrat sebagian besar berada dalam kategori baik.

Uji independent $t$ test yang dilakukan pada data FFQ menunjukkan adanya perbedaan yang bermakna asupan energi antara kelompok pekerja administrasi dan kelompok pekerja produksi. Perbedaan asupan energi pada kedua kelompok pekerja menandakan bedanya konsumsi energi yang berasal dari protein, lemak, dan karbohidrat dengan frekuensi, jenis, jumlah dalam asupan sehari-hari. Perbedaan asupan energi akibat subjek pada kelompok pekerja administrasi lebih sedikit dalam mengonsumsi jumlah makanan yang dikonsumsi, gambaran konsumsi makanan pekerja administrasi adalah satu sampai dua kali sehari dalam jumlah yang sedikit. Seperti contohnya pekerja administrasi mengonsumsi bahan makanan pokok nasi 400gr sampai 600gr sehari, sedangkan pada pekerja produksi mengonsumsi nasi 500gr sampai 900gr sehari.

Perbedaan yang signifikan juga ditemukan pada asupan lemak dari kedua kelompok pekerja dalam penelitian ini, hal ini menandakan bahwa asupan lemak pada kedua kelompok pekerja berbeda dari frekuensi, jenis (baik dari jenis makanan maupun jenis pengolahan makanan yang dikonsumsi), dan jumlahnya. Perbedaan asupan lemak dapat disebabkan karena subjek pada kelompok pekerja produksi mengonsumsi bahan makanan yang mengandung lemak lebih banyak dibandingkan pada kelompok pekerja administrasi. Seperti contohnya pada pekerja produksi dalam sehari dapat mengonsumsi gorengan tahu tempe sebanyak 2 sampai 5 kali sehari, sedangkan pada pekerja administrasi makanan seperti gorengan tahu tempe dikonsumsi 0 sampai 3 kali sehari. Asupan energi dan asupan lemak pada hasil penelitian ini berbeda dengan hasil penelitian pada pekerja dimana pada penelitian tersebut tidak adanya perbedaan antara asupan energi pada pekerja dalam ruangan dengan pekerja lapangan ${ }^{24}$ dilihat dari rerata asupan energi yang juga berbeda pada penelitian tersebut

Variabel asupan protein dan karbohidrat pada penelitian ini tidak ditemukan perbedaan yang signitifikan dari kedua kelompok pekerja dimana hal ini membuktikan bahwa secara statistik pada kedua kelompok pekerja untuk asupan protein dan karbohidrat tidak berbeda baik dari frekuensi, jenis, dan jumlah yang dikonsumsi. Asupan protein dan karbohidrat tidak berbeda dikarenakan makanan yang dikonsumsi oleh kedua kelompok pekerja sebagian besar berasal dari bahan makanan yang sama. Sumber protein dan karbohidrat terbesar pada kedua pekerja lebih banyak berasal dari nasi serta protein nabati dan protein hewani.

Status gizi merupakan hasil dari pengukuran keseimbangan antara zat-zat gizi dari makanan yang dikonsumsi dengan pengunaan zatzat gizi di dalam tubuh. ${ }^{27}$ Kejadian masalah status gizi seperti underweight dan obesitas pada pekerja dapat dipengaruhi oleh beberapa faktor. Beban kerja merupakan salah satu faktor yang mempengaruhi status gizi pekerja yang dapat dibedakan menjadi beban kerja berlebih atau berat dan beban kerja terlalu sedikit atau kurang. Risiko beban kerja yang berat sering kali menimbulkan penurunan berat badan jika tidak seimbang dengan asupan gizi yang dikonsumsi. ${ }^{6}$ Selain itu, peningkatan stress akibat kerja dapat menyebabkan peningkatan adrenalin, sehingga bila peningkatan ini tidak disertai dengan aktivitas fisik maka dapat mengakibatkan terjadinya penimbunan lemak kolesterol dan trigliserid di dalam tubuh. ${ }^{28}$

.Pada penelitian ini sebagian besar subjek kedua kelompok pekerja mempunyai status gizi normal. Kategori normal yang dilihat berdasarkan PLT dan LP pada kelompok pekerja administrasi lebih sedikit dibandingkan pada kelompok pekerja produksi, yang membuktikan bahwa pada pekerja administrasi lebih berisiko mengalami masalah status gizi. Meskipun jumlah rerata PLT dan LP pada kedua kelompok dalam kategori normal, tetapi pada hasil penelitian ini juga ditemukan masalah gizi lebih yang perlu diperhatikan. Pada kedua kelompok pekerja masalah gizi lebih memiliki persentase cukup besar, dilihat dari PLT sebanyak 45.7\% pada kedua kelompok pekerja serta persentase LP kelompok pekerja administrasi 
$37.1 \%$ dan kelompok pekerja produksi $20 \%$. Masalah ini juga akan mempengaruhi kondisi pekerja dalam melakukan pekerjaannya dan juga risiko terjadinya sindrom metabolik.

Berdasarkan PLT jumlah pekerja yang memiliki status gizi pada kedua kelompok pekerja sama yaitu sebanyak 16 pekerja, hal tersebut membuktikan bahwa pada kedua kelompok pekerja mempunyai peluang mengalami lingkar pinggang lebih dari $90 \mathrm{~cm}$. Tetapi jika dilihat dari LP, pada pekerja administrasi lebih banyak ditemukan masalah status gizi lebih yaitu sebanyak 13 pekerja dibandingkan pada pekerja produksi yang membuktikan risiko terjadinya sindrom metabolik lebih besar pada pekerja administrasi.

Selain masalah gizi lebih, pada penelitian ini juga ditemukan masalah gizi kurang pada pekerja administrasi dilihat dari variabel PLT. Subjek yang mempunyai nilai PLT terendah yaitu 5\% terdapat pada kelompok pekerja administrasi usia 24 dengan berat badan $48.1 \mathrm{~kg}$ dan tinggi badan $162.0 \mathrm{~cm}$. Subjek memiliki berat badan yang jauh dari nilai berat badan pada AKG usia tersebut yaitu sekitar $60 \mathrm{~kg}$. Hal tersebut dapat mempengaruhi kapasitas kerja yang dibuktikan oleh penelitian Annel Keys apabila berat badan 10\% dibawah berat badan seharusnya maka kapasitas kerja akan ikut turun $10 \%$ di bawah kapasitas kerja seharusnya. ${ }^{29}$

Berdasarkan uji statistik yang dilakukan pada penelitian ini diketahui bahwa PLT dan LP pada kedua kelompok pekerja menunjukkan tidak adanya perbedaan signifikan ( $p>0.05)$. Hasil ini di dukung dengan penelitian pada populasi dewasa spanyol yang menyatakan bahwa tidak adanya hubungan antara pekerjaan ringan dengan kejadian obesitas, ${ }^{4}$ dan penelitian lain yang menemukan sebagian besar pekerja pabrik mempunyai status gizi normal. ${ }^{25}$ Hasil penelitian ini sesuai dengan penelitian pada kelompok pekerja yang diketahui tidak ada perbedaan PLT pada kelompok pekerja dalam ruangan dan pekerja lapangan. ${ }^{24}$ Hasil yang sesuai dapat disebabkan karena rerata asupan lemak pada kedua penelitian sama yaitu asupan lemak lebih besar di kelompok pekerja produksi maupun pekerja lapangan pada kedua penelitian tersebut.

Hasil pada penelitian ini tidak sesuai dengan penelitian pekerja di bogor yang mempunyai hasil adanya perbedaan antara komposisi lemak tubuh pekerja ringan dan pekerja berat dan penelitian lain yang menemukan adanya perbedaan LP antara pekerja kantoran dan cleaning service. ${ }^{30,31}$ Perbedaan hasil penelitian ini dapat disebabkan karena rerata asupan energi dan protein pada pekerja berat di bogor lebih rendah dibandingkan pada pekerja ringan sehingga asupan zat gizi yang dipecah untuk menghasilkan energi tidak seimbang dengan pengeluaran energi yang dilakukan oleh pekerja berat, sedangkan pada penelitian ini rerata asupan energi dan protein lebih besar pada kelompok pekerja produksi sehingga mempunyai keseimbangan antara asupan zat gizi dengan aktivitas fisik kelompok pekerja produksi yang memerlukan energi lebih tinggi.

\section{SIMPULAN}

Asupan protein, asupan karbohidrat, persentase lemak tubuh, dan lingkar perut secara statistik tidak berbeda signifikan antara kedua kelompok pekerja, namun terdapat perbedaan aktivitas fisik intensitas berat, asupan energi dan lemak antara pekerja produksi dan pekerja administrasi. Aktivitas fisik intensitas berat, asupan energi dan lemak lebih tinggi pada pekerja produksi dibandingkan pekerja administrasi.

\section{DAFTAR PUSTAKA}

1. Melati, Srini. Hubungan Antara Umur, Masa Kerja Dan Status Gizi Dengan Kelelahan Kerja Pada Pekerja Mebel Di CV. Mercusuar Dan CV. Mariska Desa Leilem Kecamatan Sonder Kabupaten Minahasa. Fakultas Kesehatan Masyarakat. Universitas Sam Ratulangi, Manado.

2. Wilson, Lisa. A Review And Summary Of The Impact Of Malnutrition In Older People And The Reported Costs And Benefits Of Interventions. Malnutrition Task Force, 2013.

3. Ogden, CL., Margaret DC., Brian KK., Katherine MF. Prevalence Of Childhood And Adult Obesity In The United States, 2011-2012. JAMA, 2014; 311(8):806-814.

4. Fisac, Juan LG., Pilar GC., Lucia DG., Esther LG., Jose R., Fernando RA. Work-Related Physical Activity Is Not Associated With Body Mass Index And Obesity. Obesity Research, 2002.

5. Hariyati, Maulina. Pengaruh Beban Kerja Terhadap Kelelahan Kerja Pada Pekerja Linting Manual di PT Djitoe Indonesia Tobacco Surakarta. Skripsi. Universitas Sebelas Maret. Surakarta, 2011.

6. Ginting, Surita. Pengaruh Beban Kerja Terhadap Status Gizi Pekerja Peternakan Ayam Di Desa Silebo-Lebo Kabupaten Deli Serdang. Politeknik Kesehatan Kemenkes Medan, 2013.

7. Choi, Bongkyoo., Peter S., Haiou Y., et al. Sedentary Work, Low Physical Job Demand, And Obesity in US Workers. Am J Ind Med, 2010.

8. Angraini, DI. Hubungan Depresi dengan Status Gizi. Medula. Unila, 2014;2(2):39-46.

9. Prihatini, Lilis Dian. Analisis Hubungan Beban Kerja Dengan Stress Kerja Perawat Di Tiap Ruang Rawat Inap RSUD Sidikalang. Tesis. Universitas Sumatera Utara. Medan, 2007.

10. Sumamur. Higiene Perusahaan dan Kesehatan Kerja (HIPERKES). Jakarta, 2009 
11. Champagne, N., Abreu, M., Nobrega, S., et al. Obesity/Overweight And The Role Of Working Conditions: a qualitative participatory investigation. MassCOSH, 2012.

12. Lebowitz, Jason., Michael P., Craig S. The Effects Obesity And Underweight On Health. California Pharmacist, 2009.

13. Freeman, Suzanne A. Understanding Adult Overweight And Obesity. National Institute of Diabetes and Digestive and Kidney Diseases, 2012.

14. Kasiman, Sutomo. Pengaruh Makanan Pada Sindrom Metabolik. J Kardiol Indones, 2011.

15. Xu, Li. Katashima M., Yasumasu T., Li KJ. Visceral Fat Area, Waist Circumference, And Metabolic Risk Factors In Abdominally Obese Chinese Adults. Biomed Environ Sci, 2012; 25(2):141-148.

16. World Health Organization (WHO). Global Recomendations on Physical Activity for Health. 2010 .

17. Craig, Cora L., dkk. International Physical Activity Questionnaire: 12-Country Reliability and Validity. American College of Sport Medicine. 2003.

18. Lembaga Ilmu Pengetahuan Indonesia. Widyakarya Nasional Pangan dan Gizi (WNPG). Jakarta, 2004.

19. Gallagher, et al. Body Fat Ranges For Adults: Body Fat And Visceral Fat Section. Tanita, 2011.

20. Gallagher, Dympna., Steven B.H., Moonseong H., Susan A.J., Peter R M., Yoichi S. 2000. Healthy Percentage Body Fat Ranges: an Approach For Developing Guidliner Based On Body Mass Index. Am J Clin Nutr 2000; 72: 694 - 701.

21. World Health Organization (WHO). Waist Circumference And Waist Hip Ratio: Report of a WHO expert consultation. 2008.

22. Prihatini, Lilis Dian. Analisis hubungan beban kerja dengan stress kerja perawat di tiap ruang rawat inap RSUD Sidikalang. Tesis. Universitas Sumatera Utara. Medan, 2007.

23. Sefana, Tara K. Hubungan Antara Aktivitas Fisik dan Screen Time dengan Status Gizi pada SiswaSiswa SMP Kristen Eben Haezar 2 Manado. Universitas Sam Ratulangi. 2012.

24. Yuliastuti, Anik., Didit Damayanti. Perbandingan Persen Lemak Tubuh, Asupan Energi, Asupan Lemak, Kebiasaan Makan, Dan Aktivitas Fisik Pekerja Dalam Ruangan Dengan Pekerja Lapangan. Jurnal Nutrire Diaita (Ilmu Gizi). Vol 2, No2 (2010).

25. Syam, FM., Zulhaida L., Arifin S. Gambaran Asupan Zat Gizi, Status Gizi, Dan Produktivitas Kerja Pada Pekerja Pabrik Kelapa Sawit Bagerpang Estate PT. PP. Losum 2013.

26. Hulshofi KFAM, Brussaardi JH, Kruizinga AG, Telman J, and Wik L. Socioeconomic Status, Dietary Intake And 10 y Trends: The Dutch National Food Consumption Survey. European Journal of Clinical Nutrition. 2003.Vol.57; page:128-137.

27. Australian Safety and Compensation Council (ASCC). Overweight and obesity: Implications For
Workplace Health And Safety And Workers' Compensation - Scoping Paper. Australian Government, 2007.

28. Anoraga, Pandji. Psikologi kerja. Rineka Cipta. Jakarta, 2009.

29. Adriani, Merryana., Bambang W. Peranan Gizi Dalam Siklus Kehidupan. Kencanapenada media group. Jakarta, 2012.

30. Rosmalina, Yuniar., Dewi Permasih., Sri Martuti., Revianan C., Susilowati H. Keseimbangan Energi dan Komposisi Tubuh Pekerja dengan Jenis Pekerjaan Berbeda. Panel Gizi Makan 2005, 28 (1): 1-8.

31. Prastyo, Dody. Perbedaan dan Hubungan Antara Lingkar Pinggang dengan Kadar Kolesterol LDL pada Pekerja Kantoran dan Cleaning Service di RSUD Lombok Barat. Universitas Muhammadiyah. Yogyakarta, 2011. 